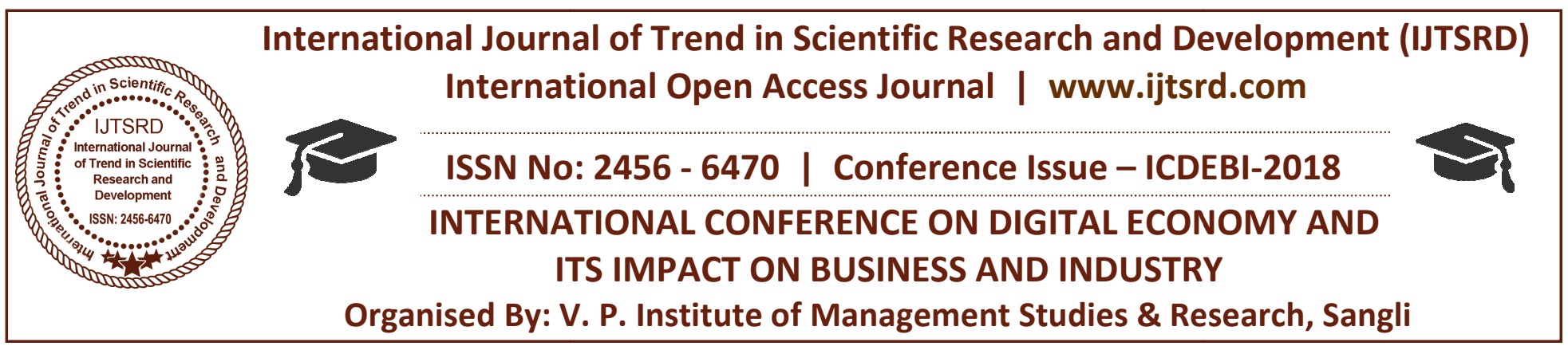

\title{
E-Governance: Contests for State Level Model
}

\author{
Dr. Abhijeetsinh Jadeja ${ }^{1}$, Mr. Vraj Bhatt ${ }^{2}$ \\ ${ }^{1}$ Assistant Professor, ${ }^{2}$ Student
}

B. P. College of Computer Studies, KSV University, Gandhinagar, Gujarat, India

\begin{abstract}
By the mean of E-governance this informative research paper focus on general trait and main criteria of challenges in front of services provide by government. When we deliberate about Information and Communication Technology (ICT) E-governance is a part of it and it provide convenient application on citizens and government. We accept India is in list of growing country; E-governance is an important key element for both citizens as well as government to increase transparency between Government-toCitizens (G2C). Same when we talked about Egovernance we must focus of some focal challenges for it as primary level in this research paper contest is categories like - Environment - Social - Economical - Technical part to build E-governance as successful model it leads to the Gross Domestic Product (GDP). Before proposed model for E-Governance we must contemplate some major aspect and challenges for the same.
\end{abstract}

KEYWORDS: Information and Communication Technology (ICT), Government - to-Citizens (C2G), Gross Domestic Product (GDP)

\section{INTRODUCTION}

E-Government can be defined as the use of information and communications technologies by governments to improve the range and quality of information and services to citizen, businesses, society organization and other government agencies in resourceful, gainful and useful manner to make government process more transparent. The main objectives that follows delivery models named Government-to-Citizen (G2C), Government-toBusiness (G2B), Government-to-Government (G2G) and Government-to-Employee (G2E).

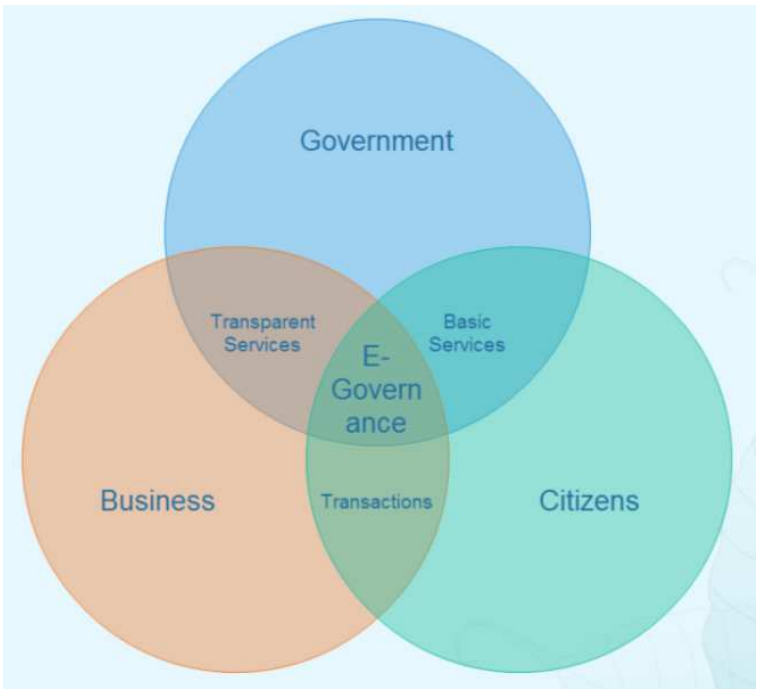

Figure 1.1 Target Agents and Services of EGovernance

\subsection{Government-to-Citizens (G2C)}

First if we discuss about G2C, it is the most basic and an important role played by the government for the citizen of the States. Likewise Baby birth - Medical Services - eliminatory, Secondary and college level quality education services not only this but motivate the citizens to convert to employees or an entrepreneur.

\subsection{Government-to-Business (G2B)}

Than we focus on G2B, government will help to business and non-profitable company for transactions such as contract bids, data collection and grants. Government should provide transparent services wherever business owners should pay liabilities and taxes to government. Government should announce various beneficiary schemes for small to MNC level business. 


\subsection{Government-to-Employee (G2E)}

An employment is directly effect to Gross Domestic Product (GDP) of any country, according to this it is decide country is in developing and developed phase this process indicates G2E. An employee responsibility and liabilities are to pay tax to the government with $100 \%$ transparency; by the collection of this tax government should provide basic services to the citizens and senior citizens. For this same any government should provide user friendly and portable taxpaying system to all the employers.

\subsection{Government-to-Government(G2G)}

Finally the growth of government that converts to EGovernance is depend depth study and pilot testing of existing E-Governance model of other states. This G2G process meets and discoveries benefits and challenges face by other E-Governance states, if we take example Gujarat as E-Governance is in developing phase and same as other side government like Bangalore, Tamil Nadu had already established E-Governance system for their state.

To any Government to E-Governance first we face so many challenges. In this research paper we find main domain challenges like Environmental and Social Challenges - Economical Challenges and Technical Challenges.

\section{Environmental and Social Challenges}

\subsection{Languages}

Gujarat State has around 6 Core populations. This population scattered into 27 districts, all these districts have various languages as pronunciation in Gujarati. Most of people do not know English language. So Government has big challenges to understand common popular languages which will worldwide accept. For this English language popularity is must.

In against of facing this issue we found literacy ration of Gujarat state, however everyone knows Gujarati as mother tongue in compare to English speaking language. So it is necessary to focus literacy ratio of Gujarat State.

\subsection{Literacy and IT- Literacy}

As per National Information Centre (NIC) statistics recent data of Gujarat literacy is $79.31 \%$ since 2011, among them rural area literacy is just $73 \%$ as compare to urban area it is $87 \%$ hence it is desirable to promote rural area education as fast for E-Governance system. Out of this population most of people do not have knowledge of computer and Information Technology. So here is a big challenge for the Government to IT awareness in each district for successful implementation for E-Governance system.

\subsection{Struggles for Changes}

Literacy and IT Literacy is a key factor for EGovernance setup model among this IT Literacy has different types of criteria like general users of IT, developer level users of IT, expert level of users in IT. Out of this E-Governance model should be develop like that general users of IT can accept - utilize service benefit - analysis (admin level). Main issue is general users' struggles how to utilize E-Governance service. In some state it is existing as a part of website - web portal but as per general survey it comes out people/citizens are not interested - they are not getting portability - depend on internet services...etc. Factors for struggling and facing a lot problem for accept changes for the better service.

It should be desirable that E-Governance model should provide services by most famous and immerging technology like "mobile app" development. By this suggestion we can come out from such struggle and changes and people will easily accept this service at $24 \times 7$ level.

\subsection{Population}

India is considered as big number of population country, among the different state if we considered as a pilot project on Gujarat State which has nearly 6 Core populations. Out of this if we considered factors like literacy - IT Literacy and then after we suggest most useful E-Governance service on Mobile app. But we still face some problem like - Unique Citizen Identification - Citizen Authentication - Genuine Data filling by Citizen - Keep Record of each Citizen - Citizen Assets Data. To manage these problem Government require more skilled and technically sound staff for various types of services.

\section{Economic challenges}

To drive E-governance Economical or financial is an important obstacles for successful setup of an Egovernance model. For this we found some important aspects of challenges as below.

\subsection{IT Infrastructure}

For every services of E-Governance we require authenticate data in proper format. To manage these huge data government need to setup big data Centre at 
different places. To manage Centre government need expert IT Engineer, Big Data Analytics and Developers. If we consider to setup Data Centre for top to bottom level services, government need to centralize all the authenticate data and connectivity between all Villages - Taluka - District and then all data collect to the Central level State Administration department. As we know national level we already established National Informatics Centre (NIC), we need to suggest State Information Centre (SIC) to provide maximum services by E-Governance. Internet is a key resource for IT Infrastructure for that Gujarat State had already established GSWAN (Gujarat State Wide Area Network). State Government has already establish services like Core Applications - Common Applications - Departmental Applications Knowledge Management Applications - File Management Applications _ Workflow \& Organization Model - Securities \& Access Control etc. If we consider all these aspects it is completely administration level, but as a key factor for end user beneficiary it recommend to build IT Infrastructure to setup Wi-Fi and best service of internet service provider (ISP) by government only.

\subsection{Portability of Applications}

To enhance the work flow and work efficiency government should provide specific device to the central administration as well as to all department and government offices which is connected with EGovernance service. For that government have big challenges for purchasing huge number of such device for their staff. So we suggest to make each services of E-Governance must have dashboard to analyze work of their department so one can check the workflow from device anywhere - anytime. Application Portability can enhance the work efficiency and transparency. Citizen will get the advantage of Application Portability in term of time to time response from government.

\subsection{Maintenance}

When we talk about huge IT Infrastructure and device portability these all means digital devices - Gadgets Networks - Data Servers - File Servers and many more. To maintain this assets government should require Technically Skilled Staff. To reduce the economic cost it is require regular maintenance and setup with minimum cost. For the individual users data security government should establish backup server also. Maintenance in sense of hardware and software as well as when emerging technology comes update themselves for this for better performance of E-governance model.

\subsection{Limited Financial Resource}

When we think about Economic challenges one should focus on Gross Domestic Product (GDP) is one of the measures of national income and a country's economy. GDP is defined as the total market value of all final goods and services produced within the country in a given period of time. GDP of a country is the measure of its financial strength. India has limited financial resources so as to implement and maintain the e-Government projects properly. If we can complete government project and new manufacturing units will increase the ratio or GDP.

\section{Technical challenges}

For successful working of an E-governance model the most important and key factor is Technical Challenges. By providing proper solution only we can come out from the following challenges of Technical level.

\subsection{User Friendly}

When we consider huge number of beneficiary, we must focus on system design part so the users of system can easily access the services. Government should give proper guidance to the users for accessing the services as well as to complete their transaction in right way. If the system is User Friendly maximum number of business, people and Citizens will proceed with E-Governance.

\subsection{Security}

To implement E-Governance the major aspect we consider is security. For the widely availability of users data government should enhance the security for Data Centre data access. We must work out on persons personal data like Income sources - medical data - Financial data privacy, so no one can access and modify others data. For that we have to apply some measures to protect individual data.

\subsection{Scope of Applications(Web Service \& App base)}

For the successful implementation of any application or app, the first step to identify the scope of application in desire manner. The application which provided by the government, it should first describe their scope so that the application implementation will be accurate. 


\subsection{Multi-Language Functionality}

When we try to implement application for general people or citizen for the state we must have to give language option to the end user, so the citizen will not face language barrier to use the application and government service. Using Multi Language Functionality will attract more number of users to use the system as well as government services.

\section{CONCLUSION}

Usage of Information and Communication Technology (ICT) is making large number of efforts behind E-governance. Many Indian state spending lots of money behind but still it is not complete by any state of India. Before taking any action on Egovernance and it's service there is need to focus on some main challenges and its aspects. The challenges like social - economical and technical attention on key issues like literacy - population - infrastructure user authentication - data storing and security. When any state government properly make survey and find apposite solution for the same.

\section{REFERENCES}

1. www.nic.in/projects

2. www.egovindia.org/egovportals.html

3. http://www.whitehouse.gov/sites/default/files/omb /assets /omb/inforeg/egovstrategy.pdf

4. http://www.gocalne.org.uk/gobetween/Backgroun d.pdf

5. http://finance.yahoo.com/news/indiasnationalinformatics-centre-builds-130000266.html
6. Saurabh kumar Garg, Steve Versteeg and Raj Kumar Buyya, Cloud computing and Distributed Systems(CLOUDS), 4th IEEE/ACM International Conference: Utility and Cloud Computing (UCC 2011), December 5-7, 2011, Melbourne, Australia.

7. Tom Butler, Joseph Feller, Andrew Pope, Paul Barry and Ciaran Murphy, Promoting knowledge sharing in government and non-government organizations using open source software. Oreste Signare, Franco Chesi, Maurizio Pallotti, CMG Italy-XIX Annual Conference, 7-9June 2005Florence-Italy, E-Governance: Challenges and opportunities.

8. David M. Eyers, Ramani Routray, Rui Zhang, Douglas Will cocks and Peter Pietzuch, Configuring large-scale storage using a middleware with machine learning, concurrency and computation: practice and experience Concurrency Computat.: Pract. Exper. (2011), pp. 1-15

9. Ake Gronlund, Thomas A. Horan, Orebo, Introducing E-Gov: History, Definitions and Issues, Communications of the Association for Information Systems (Volume 15, 2004)713-729.

10. David C. Wyld, The Cloudy Future Of Government: Cloud Computing and the Public Sector Around the World, International Journal of Web \& Semantic Technology (IJWesT), Vol1, Num 1, January 2010. 